\title{
Comparative Studies on the Clinical Applica- tion of Upper Extremity Orthotics with Ex- ternally Powered Dvices in Rehabilitation of Quadriplegic Patients due to High Cervical Cord Injury
}

\author{
by \\ Hideo Ogishima, M. D. \\ from
}

Department of Physical Medical \& Rehabilitation, Highland View Hospital, Case Western Reserve University, School of Medicine, Cleveland

Department of Physical Medicine \& Rehabilitation, San'aikai Ito Hospital, Tokyo

\begin{abstract}
The upper extremity orthoses and externally powered flexor hinge splints available today for rehabilitation of quadriplegic patients due to high cervical cord injury with specific reference to the increase in their mobility and independence are comparatively discussed.

In order to use wrist driven flexor hinge splint effectively, patients with spinal cord injury at $\mathrm{C}_{6}$ functional level (including the $\mathrm{C}_{5}$ level patients who had muscle transplant of brachioradialis to wrist extensors) must have power to lift at least $1.4 \mathrm{~kg}$ of weight voluntarily and be able to hold it at 45 degrees of wrist extension. Since the muscles lose about a grade in case of transplant, brachioradialis should be at least GOOD to NORMAL in standard muscle testi$\mathrm{ng}$ for determining the surgical indication.

In application of 4 different external power devices the following points are discussed.
\end{abstract}

1) Electrophysiological splint has disadvantages of inconsistent performance due to the extreme fatigability of the paralyzed muscle although the strength of $2-3 \mathrm{~kg}$ pinch is thought to be ideal.

2) Flexor hinge splint with McKibben muscle has advantages of mechanical dependability and short period required for training, but has disadvantages of frequent filling of $\mathrm{CO}_{2}$ gas and the pinch can be too strong for anesthetic fingers.

3) Flexor hinge splint with electric torque motor has an advantage of stopping the motor automatically according to the size of objects picked and simplicity of charging the battery overnight although the disadvantages include frequent mechanical repair and the switch control being affected by unstable postures as in the cases of McKibben muscle control.

4) Flexor hinge splint with myoelectric control has a great advantage in increasing the mobility of $\mathrm{C}_{4}$ patients who are otherwise completely dependent and also the fact myoelectric control is not affected by unstable postures is considered as an advantage while the disadvantages include the problem in patients with excessive perspiration due to the usage of surface electrodes. and the fairly long period required for training.

At present stage, combined application of flexor hinge splint with myoelectric control and balanced forearm orthoses (BFO) is far superior to an electric arm. with tongue control or multiple channel control using available muscles. 


\title{
研究と報告
}

\author{
高位脊髄 (頸髄) 損傷四肢麻痺患者の \\ リハビリテーションにおける \\ Upper Extremity Orthotics および Externally \\ Powered Device の臨床的応用比較
}

\author{
荻 島 秀 男*
}

\section{緒 言}

脊髄損傷のリハビリテーション, 特に高位（頸 髄）損傷患者の独立性の向上に関する研究は世界 の著名なリハビリテーションセンターでそれぞれ 独自の立場ですすめられている 質の普及により，これらの患者が合併症（尿路感 染, 裖瘡, 呼吸器感染など) で死亡する率が低下 し，正常人之同じ程度の予命を保つことが実際に 可能になってきたので，これらの患者のリハビリ テーションは社会的にも大きな問題である.

両下肢麻痺 (Paraplegia) の患者は，上肢が正 常で西欧での生活様式では車椅子を家庭で使用す ることが不自然でないから，リハビリテーション 関係者の努力の成果として社会的にりっぱに独立 している患者も数多いが, 四肢麻瘏, 特に高位頸 髄損傷のリハビリテーションでは医学的のみなら ず社会的にも多くの問題があることは既に述べら れている7).

機能的神経支配（脊椎レベルではなく）におけ る第 3 頸髄損傷では, 呼吸器不全または横膈膜麻 痺により $100 \%$ 死亡するが，第 4, 5, 6 のレベル では事故直後のいわゆる Spinal Shockを過ぎれ ば, それぞれの例に応じて椎弓切除, フレームに よる脊椎固定，Fusion などで理想的には事故発 生後 5 ないし 6 か月でリハビリテーション訓練開

* Case Western Reserve 大学医学部 Highland View 病院リハビリテーションセンター講師, 東 京三愛会伊藤病院リハビリテーション部長
始ができるはずである．第 7 および第 8 頸髄の損 傷では, 手指の機能がある程度（個人差が大きい が）残るから, 患者の独立性は増加する. 第 7 頸 髄節の損傷においては，訓練により Paraplegia と同じ程度までのリハビリテーションが可能であ る8).

最近に括ける米国の統計では, 交通事故, 戦傷 などで脊髄損傷の犠牲者は人口 10 万人につき約 55 の例数にも及んでいる ${ }^{9)}$. それに反して，十分 なリハビリテーション訓練の恩恵を受けている患 者は $1 / 4$ 程度である ${ }^{10)}$. 最近の傾向として, 米国 に拈ける各リハビリテーションセンターは人口 10 万人につき 60 床の脊損患者収容能力を確保す るように努力している11.

高位脊髄損傷患者のリハビリテーション訓練に はいろいろな補助器具を必要とするので, 現在の 段階ではどらしても大きなセンターでしか満足な 訓練を行ならことができない状態で, New York 大学の Institute of Rehabilitation Medicine, Case Western Reserve 大学の Highland View 病院リハビリテーションセンター, およびカリフ オルニア州の Rancho Los Amigos 病院が 3 大 センターと認められている，著者の公平な意見 では，それぞれのセンターに特色があり，いろい ろな分野でのスタッフが豊富な点では New York, 整形的な処置と独創性では Rancho Los Amigos，高位脊髄損傷四肢麻瘦患者の独立性の 向上では（補助器具を使用し訓練を行なった後 の) Highland View が優れていると考觉る。た 
表 1 筋力機能テスト国際規準

\begin{tabular}{|c|c|}
\hline 評価 & 説 明 \\
\hline $\mathrm{O}$ & 筋の収縮が全く認められないもの \\
\hline $\mathrm{T}$ & $\begin{array}{l}\text { 筋の収縮がかすかに触れうるが関節の動きはな } \\
\text { いもの }\end{array}$ \\
\hline $\mathrm{P}^{-}$ & $\begin{array}{l}\text { 重力なしの状態で機能範囲の } 1 / 2 \text { 以下しかない } \\
\text { もの) }\end{array}$ \\
\hline $\mathrm{P}$ & 重力なしの状態で全機能範囲関節が動くもの \\
\hline$P^{+}$ & $\begin{array}{l}\mathrm{P} よ り は \text { 強く, 重力に対して関節の機能範团 } \\
1 / 2 \text { 以下運動が可能のもの }\end{array}$ \\
\hline $\mathrm{F}^{-}$ & $\begin{array}{l}\text { 重力に対して } 50 \% \text { 以上 } 100 \% \text { 以下の関節運動 } \\
\text { が可能のもの }\end{array}$ \\
\hline $\mathrm{F}$ & $\begin{array}{l}\text { 重力に対して全機能範囲の関節運動が可能のも } \\
\text { の }\end{array}$ \\
\hline $\mathrm{F}^{+}$ & $\begin{array}{l}\text { 重力に対してある程度の抵抗を加えても運動可 } \\
\text { 能のもの }\end{array}$ \\
\hline $\mathrm{G}^{-}$ & $\begin{array}{l}\text { 抵抗を加えて } F^{+} \text {よりは強くても } \mathrm{G} \text { と言いきれ } \\
\text { ないもの }\end{array}$ \\
\hline G & $\begin{array}{l}\text { 検抗を加えても全関節運動範囲を可動であるが } \\
\text { 正常よりは弱いもの }\end{array}$ \\
\hline $\mathrm{N}$ & 正常 \\
\hline
\end{tabular}

* 正常の筋力の定義は力いっぱいの抵抗を加えても押 し負けない力を持ち, 全範囲内の関節運動可能の筋 をいう。疼痛および拘縮による限界は必ずそのよう に記録する。

だし問題になるのは，3センターとも患者が転院 してくる際，既に合併症を起こしていて（特に拘 縮, 尿路感染, 裖瘡）長期の訓練を必要々する場 合, 保険の患者では既に期限切れが近く，十分の 訓練期間を与えられえないケースがあり，社会的 な問題として春髄損傷患者の訓練に関する特別の 法令が世界各国で 1 日も早く施行されればと願う ものである.

スイスのように患者を事故の現場よりへリコプ ターでリハビリテーションセンターまで輸送し, 応急処置のみならずリハビリテーションの訓練も 同じ施設にて行なえるのは理想的である12)．ただ し，これは国が小さいこと，および特殊の法令を 汯けているから可能であって，各国の事情に応じ てそれぞれのシステムに一番適したリハビリテー ションを発展すべきである.

既に述べたごとく，おのおののリハビリテーシ ヨンセンターで特殊な装置おさよび補助器具を作製 して, 高位春髄損傷患者のリハビリテーションを 行なっているが，それらの実用性，可能性および 優劣，または筋力との関係を実際に比較検討した 文献が皆無である．著者は高位脊髄損傷りハビリ テーションに护る現存の Upper Extremity
Orthotics，および Exîernally Powered Devices を実際に脊損患者に忘用使用させたらえでそ の優劣比較を試みた．宜損患者に接しリハビリテ ーションに関係される医家，OT，PT の方がた に少しでも参考になればと願うしだいである。

\section{Wrist Driven Flexor Henge Splint 手根伸展を利用した Flexor Hinge Splint}

頸髄損傷四肢麻痺の場合, 第 4 または第 5 節の 損傷では，ただ 1 節のみのレベルの違いでも機能 的な可能性には大きな差があることは，リハビリ テーションの訓練を始める前から明らかなことで ある13).すなわち第 4 節の損傷では, 首の屈曲, 伸展の久可能であるが，第 5 節の場合には二頭筋 が健全で肘の屈曲が可能になる. 三頭筋が麻痺し ているので, 肘の伸展は重力を利用してのみ可能 である，訓練により両前腕を使用し(手錠様), 相当な力で卒引が可能になる。ただしこのレベル では手根の伸展が不能であるので腕橈骨筋が機能 的であれば（少なくとも国際規準で Good-Normal，表 1)，この筋を橈骨手根伸筋として移植 することにより Wrist Driven Flexor Hinge Splint を使用する可能性が現われる14)。この際 問題になるのは移植をした場合，国際規準で少な くとも一段階は筋力が低下するのでこのことを十 分考慮に入れて適応を考学るべきである.

著者が訓練した移植施行患者 8 名の中で， 5 名 はスプリントの使用が可能となったが，3名は $\mathrm{F}^{+}$程度の筋を移植したので手根の伸展は可能で もスプリントを着用した場合, その重さに対して 伸展不能となり，これらの患者のリハビリテーシ ヨンより移植後機能的にスプリントを使用するた めには最低 $\mathrm{G} の$ 規準を必要とするという結果が得 られた（スプリントは Rancho Los Amigos 方 式および Highland View 方式とも 150-180 g である).

頸髄第 6 節損傷患者では, 手根の伸展が可能で 手根関節癒着なたは運動範囲の制限がない患者で は Wrist Driven Flexor Hinge Splint の使用 が可能である.これはスプリントにより母指を固 定, 示指中指の先端が手根を伸展する際に母指に 近づき，物体をつかもことができるように工夫さ れたもので，指屈筋を手根で固定すると自動的に 


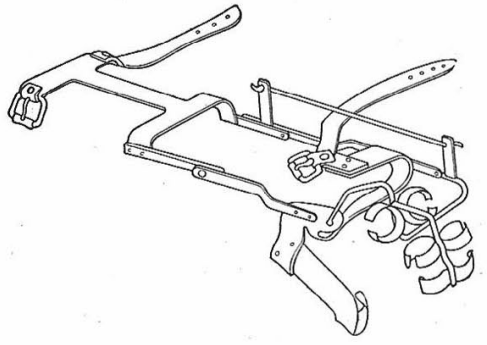

図 1 Rancho Los Amigos 方式手根伸展を利用し たスプリント

(最近は Rancho Los Amigos でも Highland View 方式に傾いている.)

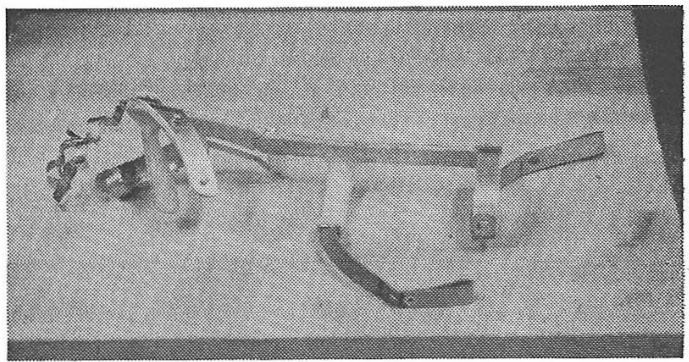

写真 1 Highland View 方式 Wrist Driven Flexor Hinge Splint

虫様筋バーが中手骨に沿っているのが特色

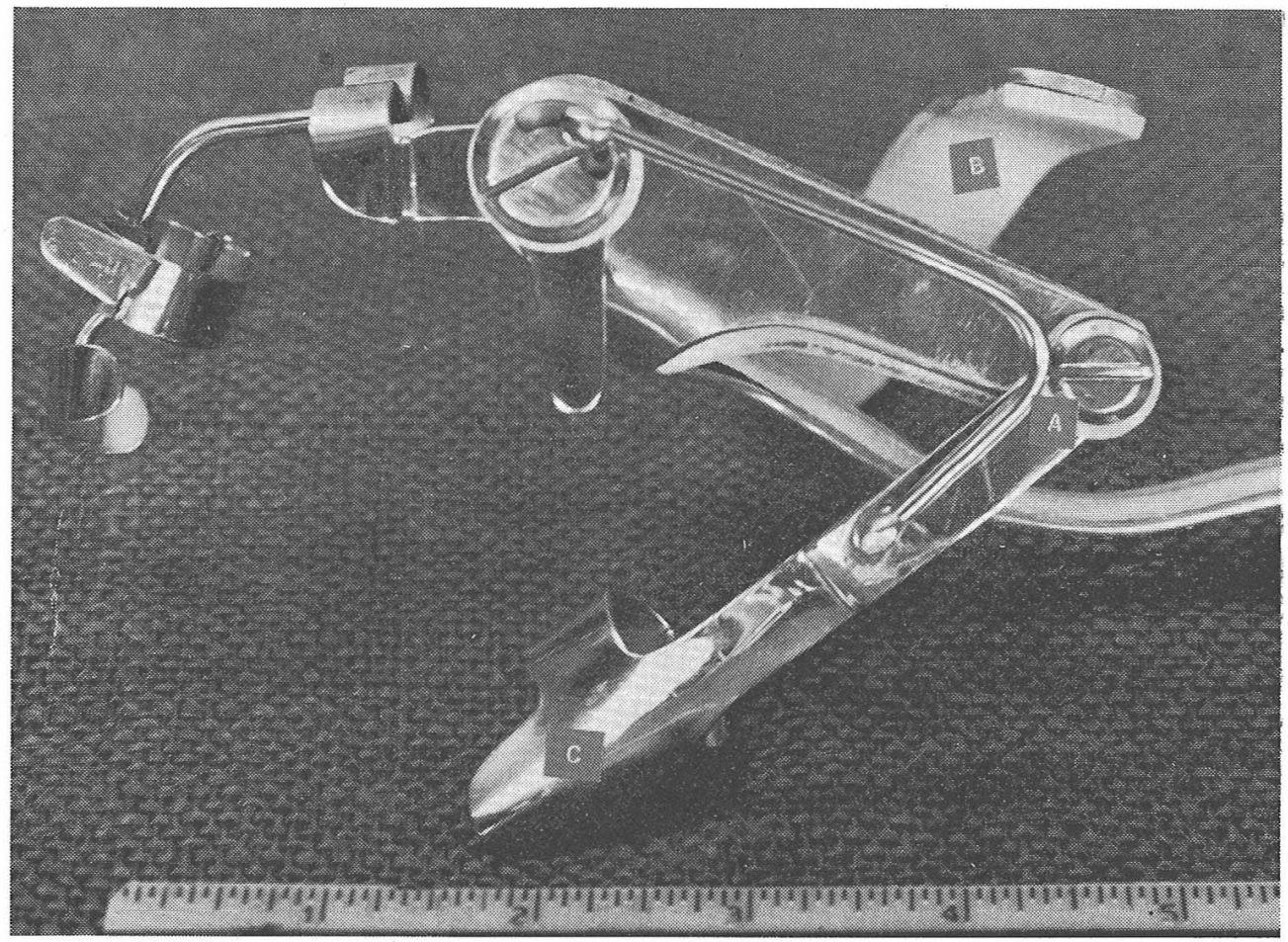

写真 2 Highland View 方式の改良型 Wrist Driven Flexor Hinge Splint

母指が内転することと主な支えが手掌側に移り，外钼がよくなっている。一A. Flexor Hinge,

B. Lumbrical Bar (or Metacarpal Bar), C. Posted Thumb with "Adduction"

手根の伸展が指の屈曲をもたら寸意味で Elexor Hinge Splint といら名がついているが, Rancho Los Amigos 病院跱よび Highland View 病院 リハビリテーションセンター両者で独自のものを 作製している．原理は全く同じであるが，Highland View 方式は 母指が完全な固定でなく示指 および中指が屈曲する際に内転するよらに工夫し てあること，中手骨の並びに沿って Lumbrical Bar が曲がっている，機能的には全く同じで
あるが，指に強直がある患者では Lumbrical Bar が中手骨と平行している点で Highland View 方式のほらが圧迫症状を起こすことが少 なく, 主な支党が手掌側にあるので外観もよく， 最近では Rancho Los Amigos 病院でも Highland View 方式を採用している(写真 1,2, 図 1). 著者はこの Wrist Driven Flexor Hinge Splint を機能的に使用でさるために必要とする手根 伸筋の筋力を正確な数值で表わしてみようと試 


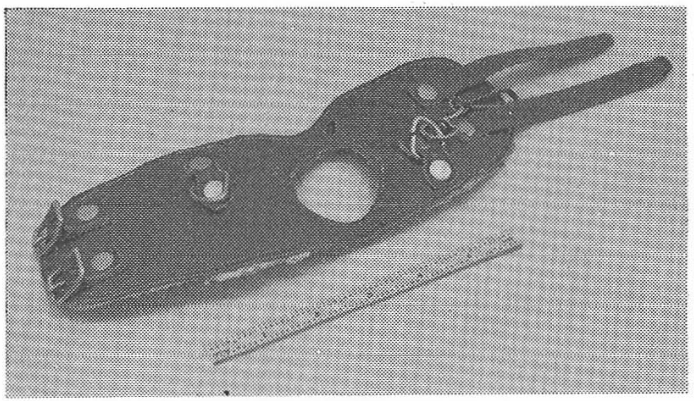

写真 3 手根伸展 (第 6 頸髄損傷患者における) 測 定用に考案したカフ

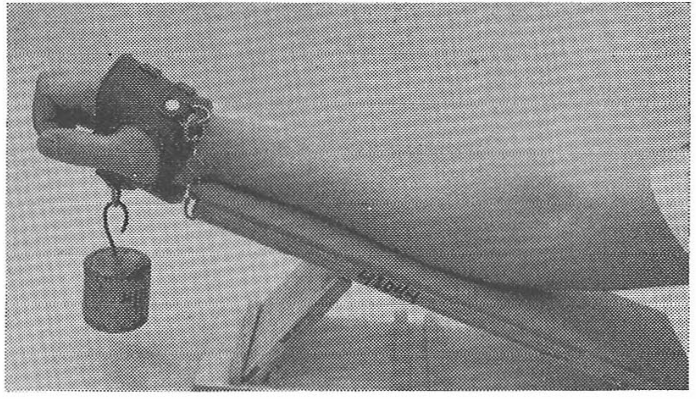

写真 4 鍾りによる手根伸展力の測定
表 2 鏵りによる筋力测定およびスプリント使用可能性との関係

\begin{tabular}{|c|c|c|c|c|c|}
\hline 患 者 & 年齡 & 性別 & $\begin{array}{l}\text { 頸䯣損傷のレ } \\
\text { ベル }\end{array}$ & $\begin{array}{l}\text { 手根仲展 } 45^{\circ} \\
\text { で支え得た錘 } \\
\text { りの限界値 }\end{array}$ & $\begin{array}{l}\text { 実際面でスプ } \\
\text { リンを機能 } \\
\text { 的に使用 }\end{array}$ \\
\hline $\begin{array}{l}\text { B. E. } \\
\text { B. L. } \\
\text { L. A. } \\
\text { M. D. } \\
\text { U. H. }\end{array}$ & $\begin{array}{l}16 \\
15 \\
18 \\
53 \\
48\end{array}$ & $\begin{array}{l}\text { 男 } \\
\text { 女 } \\
\text { 男 } \\
\text { 男 } \\
\text { 男 }\end{array}$ & $\begin{array}{l}\text { 第 } 6 \text { 頸骾損甥 } \\
5 \\
6 \\
6 \\
6\end{array}$ & $\begin{array}{r}10.5 \neq 0.04 \\
1.4 \pm 0.04 \\
9.5 \pm 0.03 \\
1.3 \pm 0.02 \\
1.7 \pm 0.02\end{array}$ & $\begin{array}{l}+ \\
+ \\
+ \\
+ \\
+\end{array}$ \\
\hline $\begin{array}{l}\text { D. B. } \\
\text { H. S. } \\
\text { V. A. } \\
\text { T. W. } \\
\text { M. S. }\end{array}$ & $\begin{array}{l}17 \\
35 \\
63 \\
14 \\
28\end{array}$ & $\begin{array}{l}\text { 女 } \\
\text { 男 } \\
\text { 男 } \\
\text { 男 } \\
\text { 男 }\end{array}$ & $\begin{array}{l}5 \\
6 \\
6 \\
5 \\
6\end{array}$ & $\begin{array}{l}0.8 \pm 0.04 \\
5.8 \pm 0.01 \\
1.8 \pm 0.01 \\
1.8 \pm 0.02 \\
2.0 \pm 0.02\end{array}$ & $\begin{array}{l}\overrightarrow{+} \\
+ \\
+ \\
+ \\
+\end{array}$ \\
\hline $\begin{array}{l}\text { S. P. } \\
\text { S. A. } \\
\text { M. S. } \\
\text { E. L. } \\
\text { A. I. }\end{array}$ & $\begin{array}{l}33 \\
21 \\
21 \\
55 \\
38\end{array}$ & $\begin{array}{l}\text { 男 } \\
\text { 男 } \\
\text { 苦 } \\
\text { 男 } \\
\text { 男 }\end{array}$ & $\begin{array}{l}6 \\
5 \\
6 \\
6 \\
5\end{array}$ & $\begin{array}{l}4.9 \pm 0.01 \\
2.0 \pm 0.01 \\
1.2 \pm 0.04 \\
6.5 \pm 0.02 \\
1.5 \pm 0.01\end{array}$ & $\begin{array}{l}+ \\
+ \\
+ \\
+ \\
+\end{array}$ \\
\hline $\begin{array}{l}\text { F. K. } \\
\text { A. B. } \\
\text { L. D. } \\
\text { F. E. } \\
\text { F. H. }\end{array}$ & $\begin{array}{l}46 \\
17 \\
18 \\
23 \\
28\end{array}$ & $\begin{array}{l}\text { 女 } \\
\text { 男 } \\
\text { 男 } \\
\text { 苦 } \\
\text { 男 }\end{array}$ & $\begin{array}{l}6 \\
6 \\
6 \\
6 \\
5\end{array}$ & $\begin{array}{l}1.8 \pm 0.01 \\
6.3 \pm 0.01 \\
2.8 \pm 0.01 \\
2.0 \pm 0.01 \\
1.4 \pm 0.01\end{array}$ & $\begin{array}{l}+ \\
+ \\
+ \\
+ \\
+\end{array}$ \\
\hline $\begin{array}{l}\text { A. M. } \\
\text { M. T. } \\
\text { A. S. } \\
\text { E. M. } \\
\text { R. N. }\end{array}$ & $\begin{array}{l}33 \\
45 \\
17 \\
34 \\
18\end{array}$ & $\begin{array}{l}\text { 男 } \\
\text { 女 } \\
\text { 男 } \\
\text { 男 } \\
\text { 男 }\end{array}$ & $\begin{array}{l}6 \\
5 \\
6 \\
6 \\
6\end{array}$ & $\begin{array}{l}1.1 \pm 0.05 \\
1.2 \pm 0.04 \\
9.8 \pm 0.01 \\
4.5 \pm 0.02 \\
1.8 \pm 0.01\end{array}$ & $\begin{array}{l}- \\
- \\
+ \\
+ \\
+\end{array}$ \\
\hline H. F. & 20 & 男 & 5 & $1.3 \pm 0.04$ & - \\
\hline
\end{tabular}

に錘りをつ沙手根を $45^{\circ}$ まで伸展でき た際の錘りの重さの限界を記録した (写真 4 ). $45^{\circ}$ の伸展が行なえれば, Wrist Driven Flexor Hinge Splint の使用が 可能であるので $45^{\circ}$ を目安 にした。この測定は一応リハビリテー ションの中期(受傷後 6 ないし 9 か月) 移植の場合は, 術後 3 ないし 4 か月に おいて，筋力がある程度安定し数值の 上下が少なくなった後 10 日間の平均 をとった (表 2).

この測定で明らかになったことは，

（a）第 5 頸䯣損傷患者で腕憢骨筋 の移植を考慮する際，国際規準によ る適応は少なくとも GないしNであ り，移殖後 $\mathrm{G}$ または $\mathrm{F}^{+}$の上で なければ Wrist Driven Flexor Hinge Splint は使用できない。

（う）スプリントを機能的に使用す るには，錘りをつけて測定した際， 手根が $45^{\circ}$ の伸展で最低 $1.4 \mathrm{~kg}$ を 支える力が必要である.

(c) 筋力が弱い患者ほぞ測定值の 日々による上下の度合が大さい。

\section{Externally Powered Orthotic Devices 外力補助により使用可能のスプリント}

第 4 およよ゙第 5 頸髄損傷（腕橈骨筋の移植によ り第 6 頸髄損傷患者之同じように手根の伸展が利 用できるようになった患者を除き）患者は基本的 には四肢麻痺であるので, 独立性の増加にはなん らかの型で外力補助を必要とする. リハビリテー 


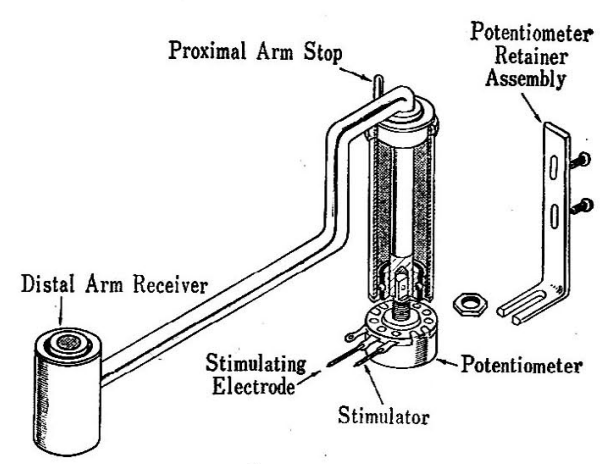

図 2 平均前腕補助器を使用した際の Electrophysiological Flexor Hinge Splint の原理

ションセンター入院中はこれらの補助器具を使用 しても退院後の行く先によって利用度は違ってい るが，現在の段階では四肢麻脾の患者で外力補助 器具を使用することにより，どの程度独立性の向 上が可能であるかということに著者は重点を置 き, リハビリテーションの過程で綮損患者には現 在可能性があるすべての器具を説明して, 最後に 決定する器具の選択は訓練を行なった後, 患者お よび家族を集めて優劣を検討し，おのおのの患者 の立場に最も適した外力補助器具を退院の際に与 えるよらにしている。

外力補助器具を使用するに際して，まず問題と なるのは次の 4 項である.すなわち，

a) 機械的に故障がないこと

b) 外観があまり大げさでないこと c) とりつけが簡単であること

d）実際にこれらの器具を使用することによって独立 性の向上が確定的であること

でする。

高位䫷髄損傷患者のリハビリテーション訓練に 関しては, Rancho Los Amigos 病院および Highland View のリハビリテーションセンターの 両者でしのぎを削っている現状である．著者は幸 い多くの患者の自主的協力を得，いろいろな外力 補助器具を制限なく使える幸運に恵まれたので， 公平な立場で実際にこれらの器具を臨床的に応用 し, 患者の訓練を行ない外力補助器具の優劣比較 検討を行なった.

外力補助によって使用するスプリントは，すべ て Flexor Hinge Splint で手根の伸展の代用と して外力を使用するわけである. 現在応用可能な 外力補助によるスプリントは大きく分けて次の 4 種類である.すなわち,
a) 電気生理反射スプリント
b) 人工筋スプリント
c) 電動モータースプリント
d) 筋電〜モーモースプリント

であるが，各地のリハビリテーションではこれら のどれかを主に使用しているようで，全部の外か を同じ患者に応用し優劣を比較検討した試みは、 著者がはじめてと思われる。

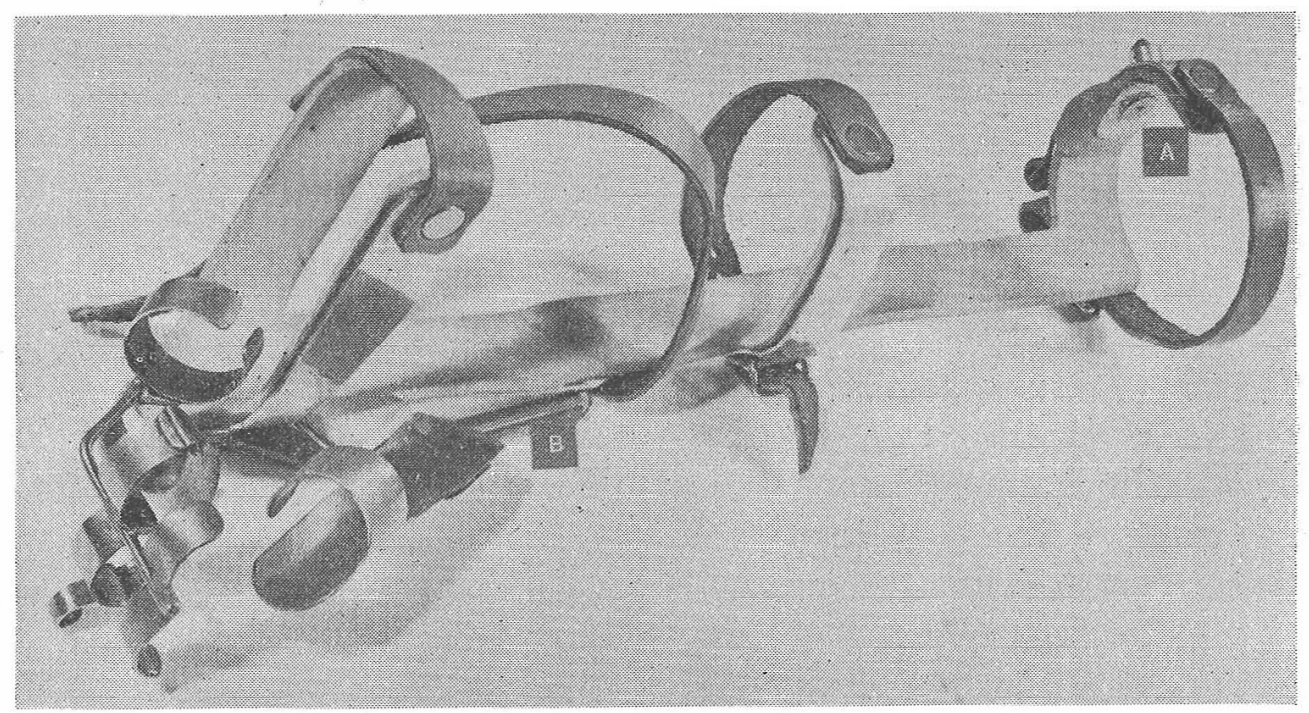

写真 5 A. 長総指伸筋の運動点にちょうどくるように設置 (刺激用の電極)，B．スプリング補助 


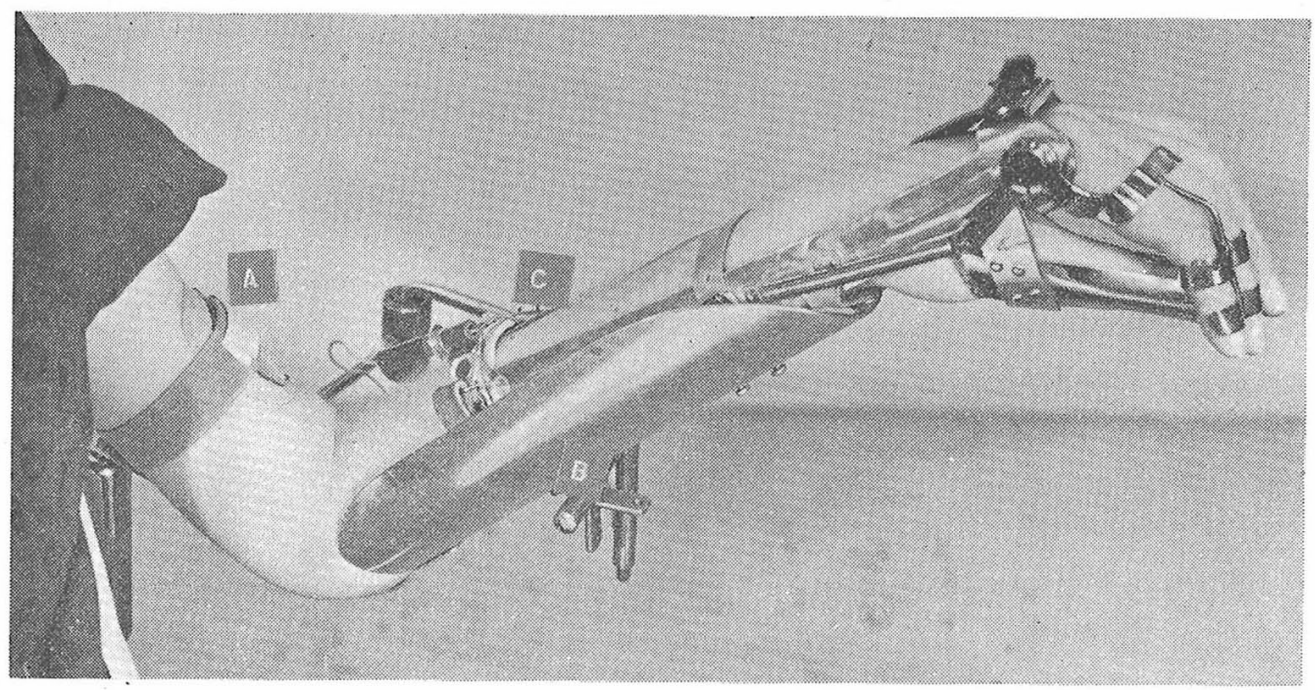

写真 6

A. 2 頭筇より筋電力をピックアップして増幅し剌激に利用する

B. 平行前腕補助器 C. 刺激電極

1. 電気生理反射スプリント. Electrophysiological Flexor Hinge Splint (図 2, 写真 5, 6)

これは Highland Vien 病院リハビリテーショ ンセンターで工夫されたスプリントで，過去 4 年 間実際に患者に使用した著者の意見では理論的な 試みとしては成功であるが，臨床面では不成功で ある．高位脊髄損傷の患者で筋麻痺があっても， 電気刺激を与えると筋が収縮を起こす生理的現象 を利用したスプリントである，寸なわち同側の神 経支配が健全である筋の上に電極を置き，それか ら起こる筋電力を増幅して，それより末端にある 麻瘴筋に刺激を送り収縮させようと試みたもので ある. 著者は第 5 頸髄損傷四肢麻痺で二頭筋が健 全であった 10 名でこのスプリントを使用してみ た.すなわち二頭筋で起こった筋電力を増幅し て, 手指伸筋の運動点に送り, その際の収縮でス プリントを操作した。ただし利点よりも欠点のほ 敃大きく，結局 10 名全員最終的には別の方式 に落ち着いた。この試みによる著者の意見では， この方式のスプリントに関して, 利点と欠点は次 のとおりである。

利点 (i ) 同側飞電極を施置するので本人が自分で 操作しているという自覚に強いこと

(ii) ちょらど指先で $2-3 \mathrm{~kg}$ の強さのスプ リントなので物を摘むのに適当な力である
こと

(iii) あまり部品が大げさでないこと

欠点 (i ) 麻痷筋 (この際は総指伸筋) が連続的に 電気刺激を受けると極度に疲労する. 4-5 回の連続刺激でスプリントの操作が不能にな るほど筋の収縮力が低下すること

(ii) スプリントを着けるたびに運動点を確か めなければならないので家族に頼るのは技術 的に困難であること

(iii) 刺激によって起こる麻痺筋の収縮は閗值 によって左右されるので細かいコントローネ が不能であり，スプリントの開閉がスムーズ ではない。

2. マッキボン筋によるスプリント Mckibben Muscle Control Flexor Hinge Splint (写真 7,8$)$

この人工筋は Rancho Los Amigos 病院で考 案された特殊な織り方をしたナイロンの筋で，内 部にゴムのチューブが入り，これを炭酸ガスで膨 張させると笳が収縮する仕組みになっている。ガ スの弁の制御は僧帽筋を主に利用し，肩の上下隼 動により可能である。この弁は特殊な弁で適当な ところで，スプリントの開闒を調節することがで きる、第 4 执よび第 5 頸髄損傷で入所した可ベて の患者に一応チャンスを与えて，このスス゚リン* の使用訓練させることを原則としているが，拘縮 が強くて指の屈伸が不能なもの，护よび高齢者で 


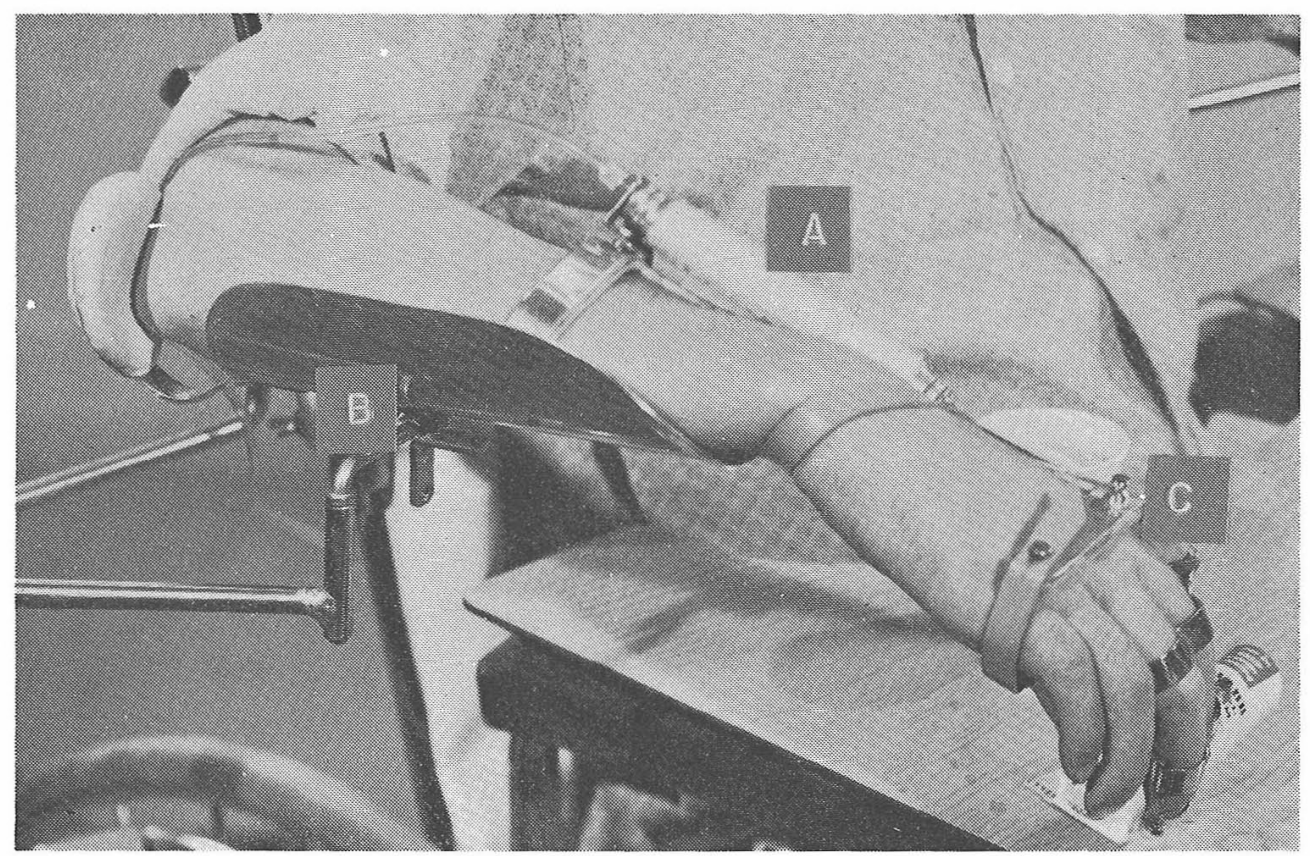

写真 7 McKibben Muscle Controle Flexor Hinge Splint
A.マッキボン筋
B. 平均前腕補助器
C. Flexor Hinge

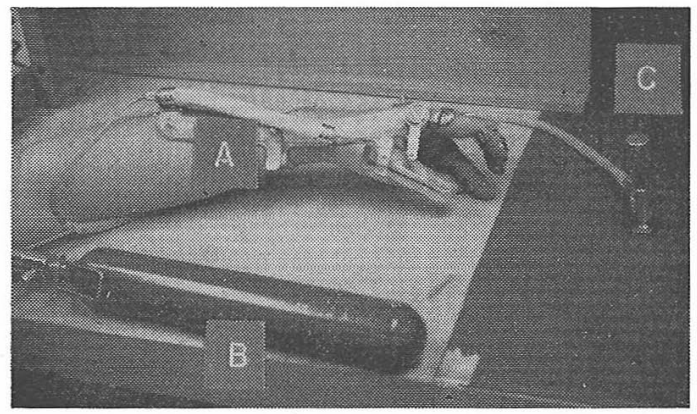

写真 8 McKibben Muscle Control Flexor Hinge Splint (必要コニット)
A. マッキボン筋
B. 炭酸ガス用のボンべ(車椅子のシートの上に普 通設置)
C. 屃に設置するガスコントロール用のバルブ

全く自主的に興味を示さない患者は除外した，

損傷後頸推が安定車椅子で $90^{\circ}$ までの座位を 2 時間保ら, 血圧值の変化が起こらない患者はすべ て対象となり平均腕補助器 ${ }^{15)}$ Balanced Forearm Orthoses (BFO) の訓練が終了後ただちにスプ リントを与えて訓練を行なった， 4 年間で著者が 訓練を行なった 24 名の患者すべて 1 日でこの操 作を覚えることができるが，トランプ遊び，食 事, 本のページめくりなどが自由にできるように

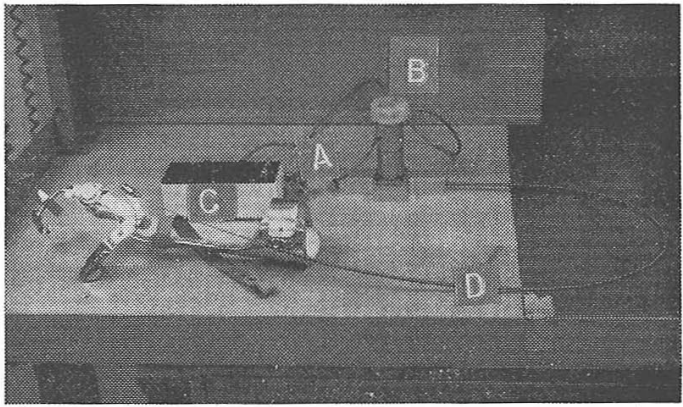

写真 9 Electric Torque Motor Control Flexor Hinge Splint
A. スイッチ
B. モーター
C. バッテリー (12V)
D. テーブル

なるには, 早い患者で 3 日間, 遅い患者で約 2 週 間の訓練期間を必要とした。このスプリントに関 する著者の意見は次のと拈りである。

利点 （i） マッキボン筋の反応時間はガスを送って $0.8-1$ 秒で遅れが少ないので患者がはじめ から喜んで受け入れてくれること

(ii) 故障がほとんどないこと

(iii) 安価であること

(iv) 訓練が割合簡単であること

欠点（i）近くに炭酸ガスボンべを補充する施設が なければ使用できないこと（普通の使用で携 帯用ボンベは 1 週間ほど使用できる) 


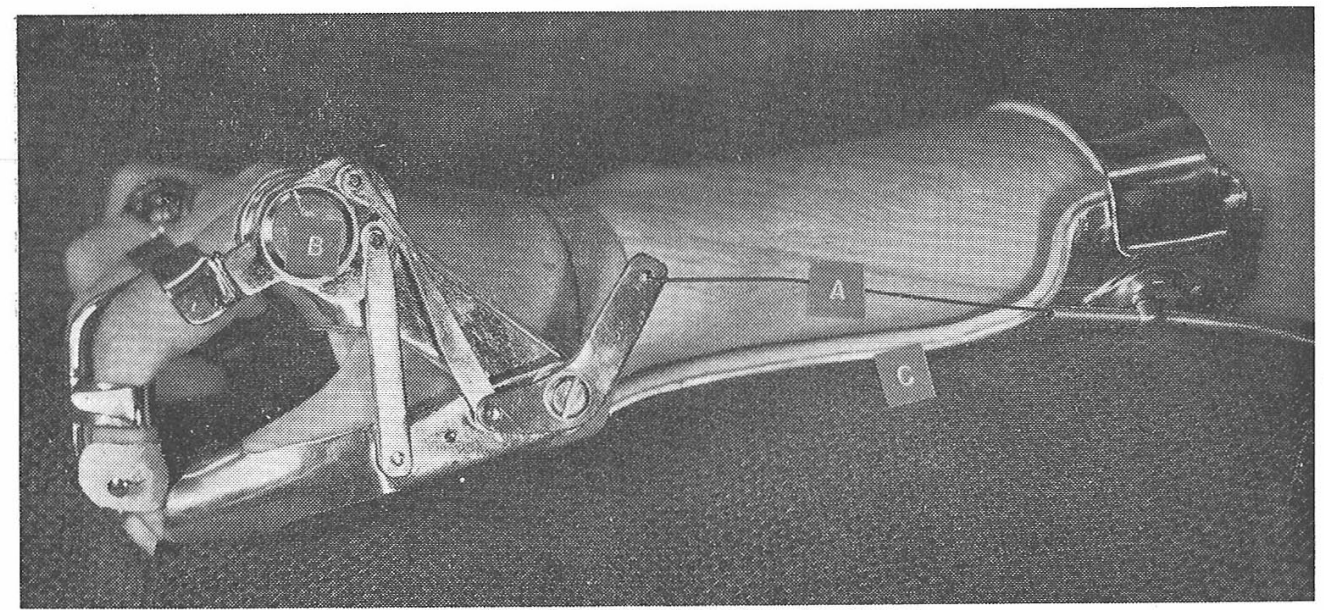

写真 10 Electric Torque Motor Control Flexor Hinge Splint
A. テーブル
B. Flexor Hinge
C. Volar Support

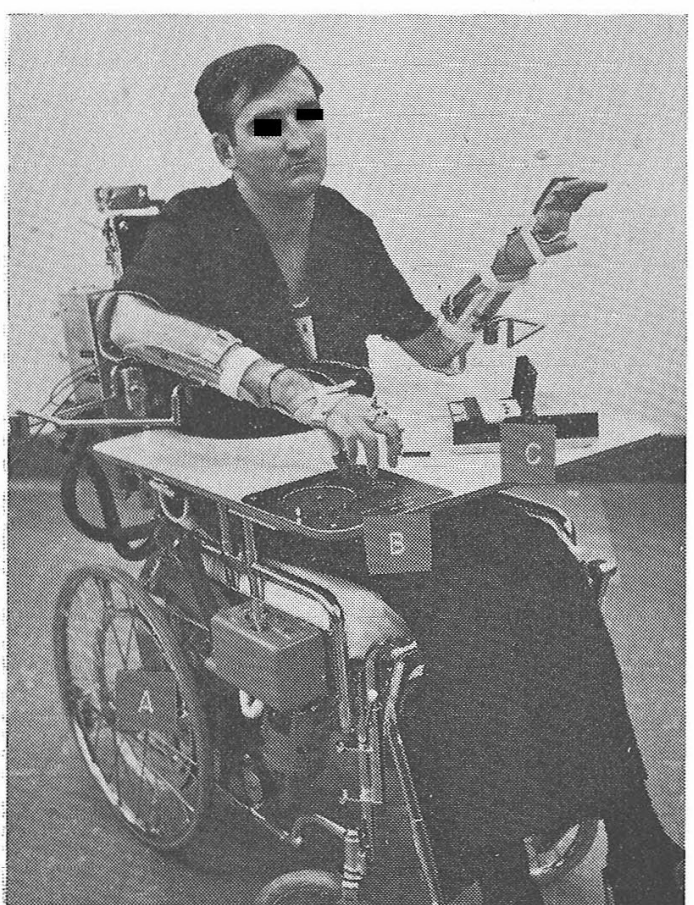

(ii) 肩の上下により弁の制御を行なうので真 直の坐位でしか弁のコントロールができない こと（特に姿勢の悪い患者では使用不能）

(iii) マッキボン筋を使用した場合, 指先で 4-5 kg の圧迫が可能であるため(特にこれ らの患者は知覚麻㾇があるので) 注意しない と指先に血腫を作ることがある

3. 電気モーターによるスプリント Electric Toroue Motor Control Flexor Hinge Splint

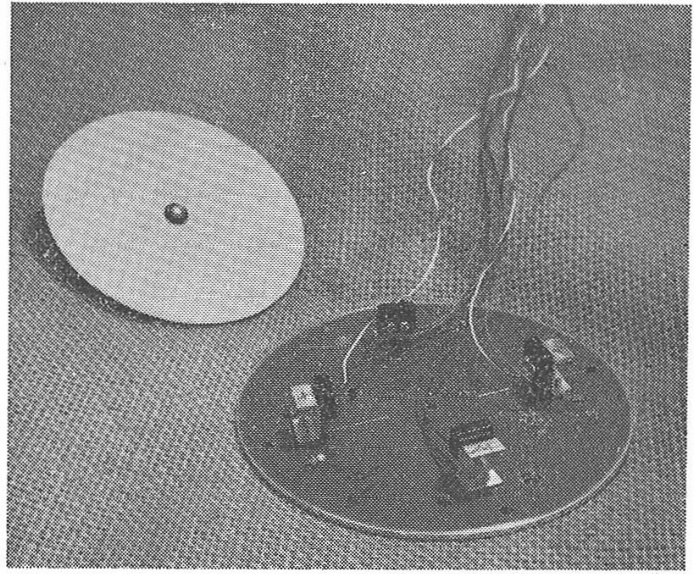

写真 11 (左)

A. 露動㥓子

B. 車椅子のためのマイクロスイッチ (写真 11-suppl. 参照)

C. 簙義出席のためのテープレコーダー

写真 11-supplement (上) マイクロスイッチ（この 円板に触れた方向へ車が動くようにくふうされてい

る)

Rancho Los Amigos 病院で使用をはじめた 後, 各所で改良され著者が患者に応用したものは Highland View で更に改良を加えたものである (写真 9,10$)$.

ケーブルの延縮によりスプリントの開閉を行な らもので, $12 \mathrm{~V}$ のバッテリーを使用, マッキボン 筋方式と同じようにスイッチを肩の近くに設置, 肩の運動心よりスイッチのコントロールを行ない モーターが右まわり左まわり両方可能厄工夫され 


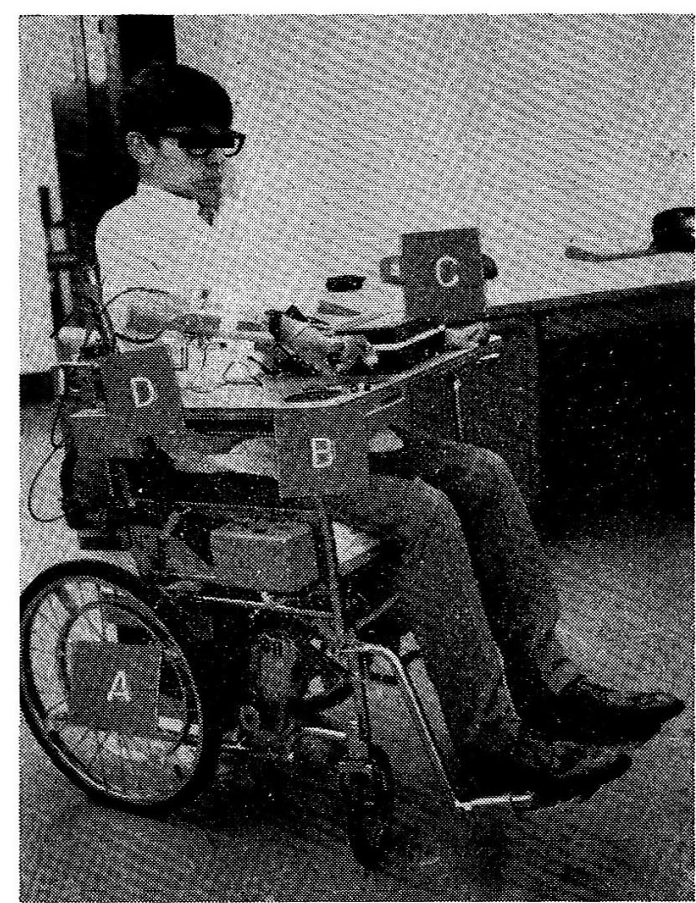

写真 1211 と同じく第 4 頸檤損傷患者の独立性を 向上させた Myoelectric Control Flexor Hinge Splint と Balanced Forearm Orthoses の組み合わ せ
A. 電動車椅子
B. マイクロスイッチ
C. テープレコーダー
D. $\mathrm{BFO}$ のニニット

ているもので，マッキボン筋によるスプリントを 使用した 24 名の患者全部にこの方式を使用させ てその優劣を検討してみた。

利点（i） バッテリーの充電が家庭で可能であるこ と(患者が睡眠中毎晚充電を行なう)

(ii），物を摘んだところでモーターが止まるの で指を圧迫し，血腫を作ることがなく，知覚 麻㽻の患者に使用して危険性が少ない

(iii) 訓練が比較的簡単である

欠点 (i) マッキボン筋スプリントと同じくスイッ チが定着位置にあるため姿勢が悪い患者には 使用できない

(ii） スイッチに故障が起こることが多い

(iii) 逆まわりの際，モーターの音がかなり大 きい

4. 筋電力によるスプリント Myoelectric Co: ntrol Flexor Hinge Splint

こ扎は Highland View に拈いて過去 3 年間 に工夫され改良されたスプリントで，第 4 頸髄麻 瘏患者 12 名以試みて成功した（写真 $11,12,13$, および 11 Supplement).

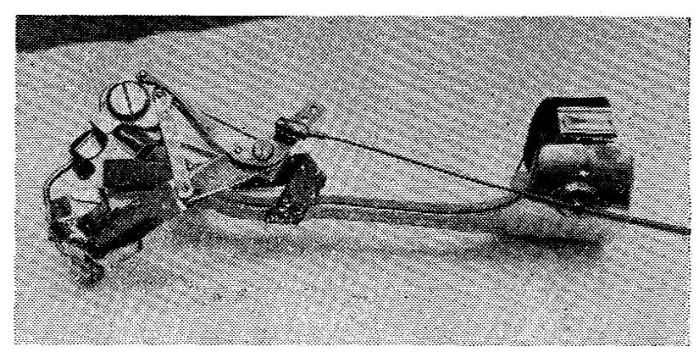

写真 13 Myoelectric Control 使用した Highland View 方式の Flexor Hinge Splint

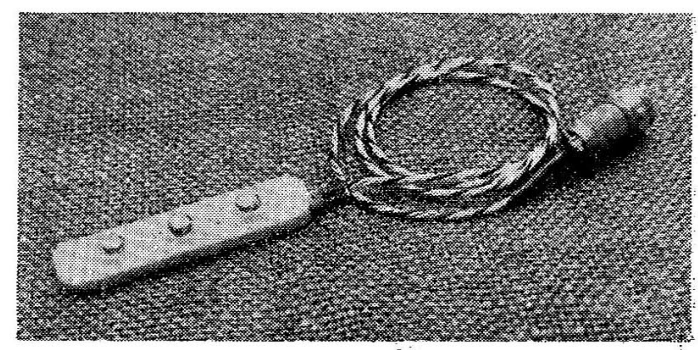

写真 14 第 4 頸髄損傷患者の独立性の増加に使用 した Myoelectric Control Flexor Hinge Splint に打㜔面電極（僧帽筋用）

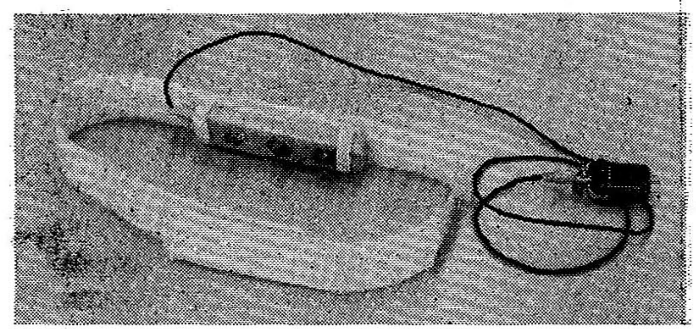

写真 15 第 4 頚髄損傷患者の独立性の増加に使用: した, Myoelectric Control Flexor Hinge Splint: に尔ける表面電極（闊頸筋用）

すなおち表面電極を使用して (写真 $14,15,16)$ 僧帽筋または濶頸筋にテープで貼りつけ，筋肉の? 收縮を強弱にコントロールすることにより，この 起こった筋電力を増幅モーターを右まわり报よ゙ 左をわりにしようとコントロールされたスプリシ トで, このモーターがケーブルの延縮を行ない, スプリントの開閍を行なら。これらの 12 名の患 者は，すべて第4節の完全切断で，このスプリン トがなければ床に卧したままか椅子にただ坐って いるだけである。

この特殊装置により，上肢の独立性を向上させ 車椅子のテーブルにつけられた Micro-Switchを 使用することにより電動車椅子の運転が可能にな ったことは高位脊髄患者のリハビリテーションに 


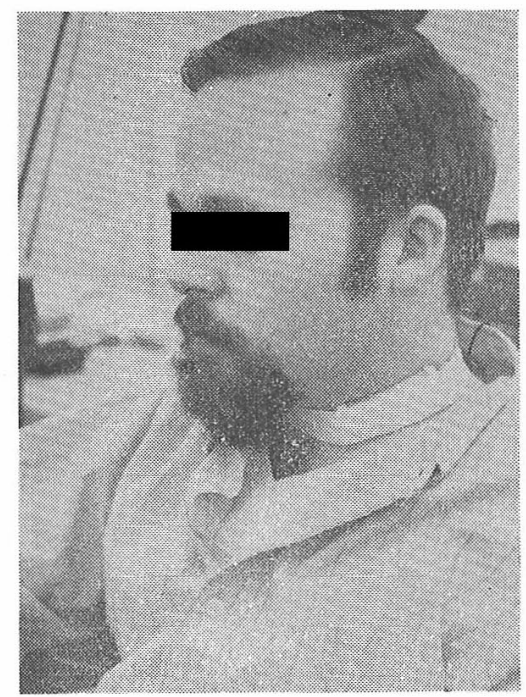

写真 16 闊頸笳を利用した際の電極の位置

お汀る過去 5 年間における最も大きな進歩と著者 は断言する。著者が訓練を行なったこれらの 12 名の患者の中で， 3 名は現在大学在学中，4名は 通信教育により大学受講中， 3 名は通信教育によ り高校課程受講中，2名は合併症のため現在まだ 大院中であるが，近々退院の予定である.

著者の経験による優劣の検討は次のと执りであ る.

利点（i）この特殊スプリントなしには病床でただ 安静か椅子に坐ったきりで, 首の運動しか行 なえない患者にある程度の独立性を与号るこ とが可能である. 特に東椅子が電動であれば 運転可能で，身体障害者を受け入れる施設の ある学校へ入ることが可能となる.

(ii) 自分の筋の収縮によってスプリントの開 閉を行ならので，自己満足が大である。

(iii) 皮䖉表面電極堂使用するので患者の姿勢 がどんなに悪くても使用できる.

欠点 (i) 表面電極を使用寸るので多汗症の患者で は冷房装置のある所でしか 100\%の能率が出 ない。

(ii) 筋の収縮の強弱に関して閾值を覚えて自 由にコントロールできるまで最近 1 週間ない し10 日間の訓練を必要とする.

これらの方式の他に最近は電動上肢（歯または 舌でスイッチのコントロールを行ならもの）の応 用行なっているが，今のところ例数が少なく (3 例) 優劣の比較までには至らない(写真 17).

電動上肢の場合は順に 1 つの関節を動かす（肩，

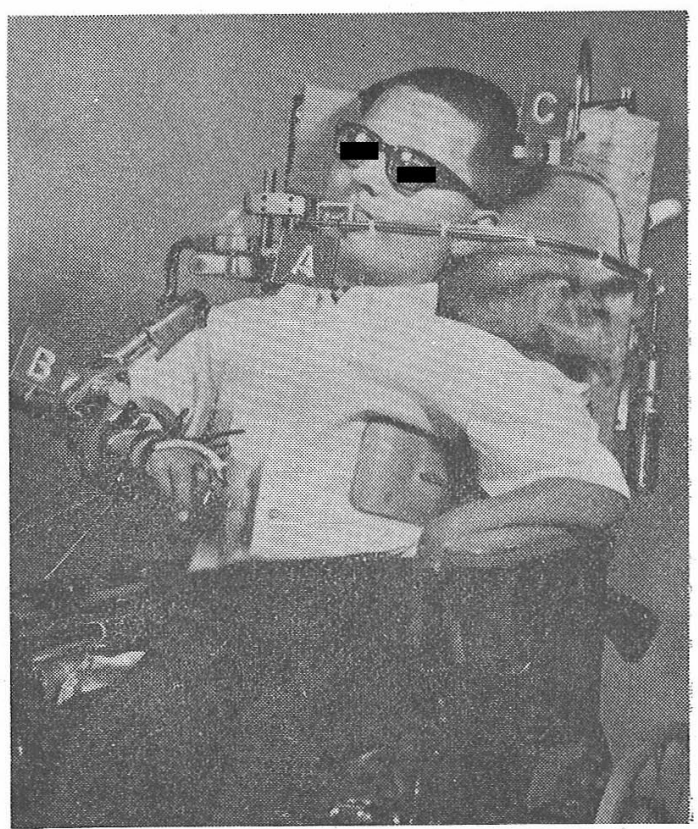

写真 17 四肢麻痺の患者に利用できる丽動上肢
A. スイッチ
B. 電動上肢
C. 頭スイッチ

肘, 手根といら順) 仕組みなので，1つの動作に 時間がかかり患者に受け入れが悪いようである。 だから現在 Highland View ではいろいろな運動 の際の各関節の角度を電子計算機に覚えさせて, これを xyz の立体的三軸儿おきか光，一度に全 部の関節が動くように工夫している(写真 18, 19)。 著者の意見では，電動上肢はあくまでもリサーチ の段階で, 実際問題としては BFO に上述の 4 つ のスプリントのどれかを組み合わせたほらが安価 で，今のところでは時閒的能率もはるかに上であ る.

これらの Externally Powered Devices はそ れぞれ優劣があるので, 訓練の際仕組みをよく患

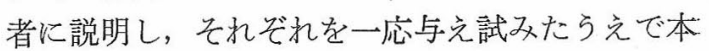
人の意向，家族の協力度，将来の方針などをよく 話し合ったうえでどのシステムによるスプリント が最適かを決定すべきであり，先大感を持って医 師が自分の考えのみで決定を下すのは禁物であ る。またこれらの患者の指導訓練中は, 理学療法 士, 作業療法士も, これらのシステムの優劣を十 分理解したらえで, 患者のリ八ビリテーション指 導訓練にあたることがたいせつなことはいうまで 


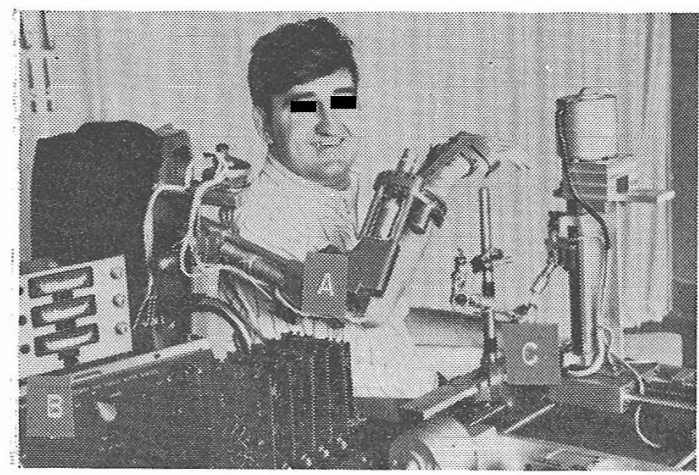

写真 $18 \mathrm{xyz}$ 軸のコントロールによる電動上肢. 両僧帽筋と菱形筋を使用

A. 電動上肢 $\quad$ B. 訓練用ボックス C. 電動上肢のミニモデル(視界による feed back のために特に訓練中必要であ る.)

为ない。

\section{総 括}

著者は増加の傾向に㐫る脊髄損傷患者, 特に高 位脊髄損傷患者のリハビリテーションに括いて独 立性の向上に手根伸展を利用した Flexor Hinge Splint，和よび外力補助を利用したスプリント 4 種 Externally Powered Orthotic Devices 際患者に応用した臨床面の立場より，それぞれの 優劣を比較検討して次の所見を得た。

第 6 頚髄損傷患者（第 5 頸髄損傷患者で腕橈骨 筋の移植を行なった 8 名を含み) 26 名に打いて 手根伸展利用による Flexor Hinge Splint を使 用するには，

（i） 最低 $1.4 \mathrm{~kg}$ の鍾りを $45^{\circ}$ で支觉る力が手根伸

筋 (橈側) に必要である.

(ii) 腕橈骨筋を移植するには筋力が国際規準で GNでなければならない。

(iii) 筋力が弱いほど日々の違いが大きい.

4 種の Externally Powexd Orthotic Devices の高位脊髄損傷患者のリハビリテーションに 排ける臨床的応用では，

1）電気生理反射スプリントを第 5 頸髄損傷患 者 10 名に応用, 麻瘏筋の疲労度が強いこと, お .よび開閉がスムーズでないことが欠点で, 指先の 力が $2-3 \mathrm{~kg}$ で適当であることは利点と思われ た。

2）マッキボン筋によるスプリントを第 4, 5 頸

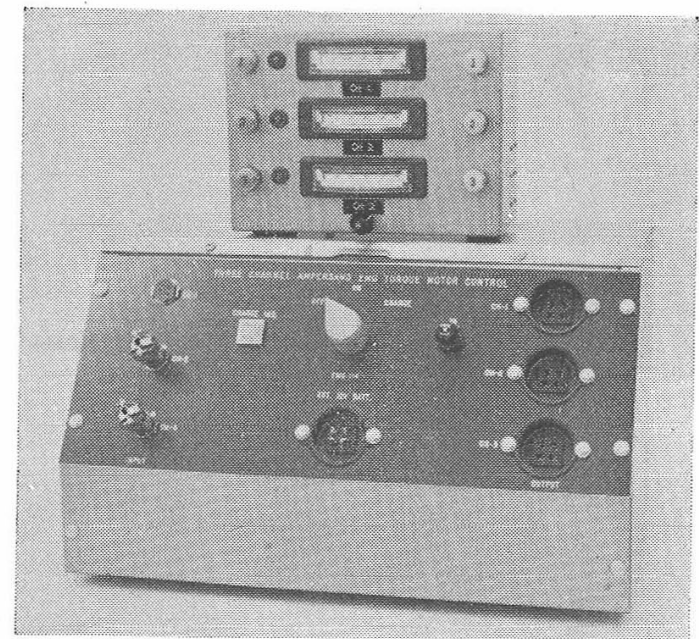

写真 19 第 4 頸䯣損傷四肢麻痻患者のリハビリテ ーションで，3つの筋により 6 つの運動をコントロ ールするために, 筋の収縮の度合いを訓練するボッ クスで，6つのランプを自由に組み合わせ可能にな るむで訓練する。

髄損傷患者 24 名に応用, 短期訓練可能性および 故障がほとんどないことが利点で，炭酸ガスボン ベの補充が遠隔地では不能であることと力が強す ぎて 知覚麻痺患者の指先に 血腫を作ることがあ り，これは欠点と思われた。

3）電気モーターによるスプリントをマッキボ ン筋のグループと同じ 24 名の患者に応用, 物体 をつかむ際，物体の大きさに応じてモーターが止 ぬること，およびバッテリーの充電が簡単なこと は利点で, スイッチに故障が多いことと, マッボ ンと同じく姿勢が悪い患者では応用が困難である ことが欠点と思われた。

4) 筋電力によるスプリントを第 4 頸骾損傷患 者 12 名に応用, 姿勢が悪い患者でも使用可能 で，独立性がこのレベルの患者では劇的に増加す る事実が利点. 多汗症の患者では冷房設備を必要 とすることと訓練に長期間要することが久点と思 われた。

更に現在の段階では四肢麻疩患者のリハビリテ ーションに関して，電動上肢より Balanced Forearm orthoses $k$ Externally Powered Flexor Hinge Splint を組み合わせたほうが実際面で独 立性の向上に，はるかに優れていることを断言す る. 
稿を終えるにあたり，ご校閲を睗った久留米大学医学 部整形外科教室宮城教授之, 公衆衛生学教室山口教授に 感謝いたします。 また過去 4 年間あらゆる面で協力を得 た Case Western Reserve 大学 Highland View 病院 リハビリテーションセンターのスタッフ，特に所長の Charles Long 博士, Chief Orthotist $の$ Vincent Masciarelli 氏に深謝します.

本論文の要旨は 1969 年 3 月 8 日, オハイオ州立大学 で Robert Bennett 博士を迎えての “四肢麻痺患者のリ ハビリテーション゙”特別集会で発表した.

\section{Bibliography}

1) Allen, J. R., Karchack, A., Snelson, R. and Nickel, V. L. : Design \& Application of External Power and Control of Orthotic Devices, American Society of Mechanical Engineering Journal, 84, 52, 1962.

2) Scott, R. N., Thompson, G. B. : Orthotic Systems Research Progress Report No. 3, University of New Brunswick, Canada, 1964.

3) Long, Charles : Upper Limb Bracing in Orthotics Etcetera, Physical Medicine Library IX, 221, Elizabeth Licht Publisher, New Haven, 1966.

4) Ampersand Annual Report: Ampersand Group for Medical Engineering, Highland View Hospital, September 1967.

5) Nickel, V., Project Director : "Progress Report : Investigation of Externally Powered Orthotic Devices" Rancho-Los Amigos Hospital, 1967.

6) Friedland, Fritz : Rehabilitation in Spinal
Cord Injuries in Rehabilitation Medicine, $\mathrm{Ph}$ ysical Medicine Library X, 460, Elizabeth Licht Publisher, New Haven, 1968.

7) Ogishima, Hideo : Rehabilitation of Spinal Cord Injuries and Responsibility of Society, The Journal of the Kurume Medical Association, 30, 599, 1967.

8) Symington, D., Mackay, D. : Study of Functional Independence in the Quadriplegic Patient: Archives of Physical Medicine \& Rehabilitation, 47, 378, 1966.

9) 10) 11) Symposium : Current Concepts on Management of the Spinal Cord Injured $\mathrm{Pa}$ tients, December 6, 7, 8, Miami, Florida, 1968.

12) Ogishima, Hideo : Site-visit to Institute of Rehabilitation Medicine University of Geneva, Switzerland, May 1968.

13) Long, Charles : Spinal Cord Lesions and Functional Significance, Handbook of Physical Medicine and Rehabilitation, Saunders, Philadelphia, 1965.

14) Freehafer, A., Mast, W. : Transfer of the Brachioradialis to Improve Wrist Extension in High Spinal Cord Injury, Journal of Bo-. ne \& Joint Surgery, 49-A, 648, 1967.

15) Occupational Therapy Department, Rancho Los Amigos Hospital : Mobile Arm Supports ; Ball Bearing, Suspension \& Friction Fee-ders ; parts \& their Function, Rancho Los, Amigos Hospital Document OT/OL-711, 1964.

編集委員長大島 良 雄

編 集委員相沢豊三天児民和江副勉

切替一郎 小池文英 小 林 太刀夫

佐々木智也* 佐藤孝三鹿野信一

田口恒夫津山直一松本淳*

水 野 祥太郎 (五十音順 * 編集幹事) 